\title{
Application of Metadiscourse to College English Writing*
}

\author{
Xi Li \\ Department of Foreign Language Xiangsihu College of Guangxi University for Nationalities Nanning, Guangxi Province, China \\ lixi8296@163.com
}

\begin{abstract}
Metadiscourse is used to negotiate interactional meanings in a text, assisting the writer to express a viewpoint and engage with readers as members of a particular community. It is classified into interactive and interactional resources. Inadequacy of metadiscourse devices may cause students' low grades in CET4 compositions. It is feasible to apply metadiscourse to English writing so as to enhance college students' writing competence.
\end{abstract}

Index Terms - metadiscourse. English writing

\section{Introduction}

English writing, which is an output in language learning, plays an important role in evaluating and enhancing a learner's English capability. Scholars at home and abroad have already done a lot of researches in English writing, but few studies are aimed at students from independent colleges. Compared with those from key universities and colleges, students of independent colleges have unsound English foundation. Their low English levels are shown in failure in writing and low grades in CET 4 and CET 6 compositions.

Metadiscourse is a terminology in discourse analysis and language teaching. It is used to organize texts, express author's view and call for reader's response. It has been studied from various perspectives, by different methods and within appropriate frameworks. In recent years, research results have been applied to English writing and throw light on English teaching. It is of significance to combine metadiscourse with teaching English writing in the context of independent college.

\section{Overview of Metadiscourse}

The term metadiscourse was first introduced by Harris [1] in 1959 as a way of understanding language in use, representing a writer's or speaker's attempts to guide a receiver's perception of a text. It was later developed and applied in writing by Vande Kopple[2], Crismore[3] and Hyland[4]. Vande Kopple defines metadiscourse as the linguistic material which does not add propositional information but which signals the presence of an author. Crismore refers to it as the author's intrusion into the discourse, either explicitly or non-explicitly, to direct rather than inform, showing readers how to understand what is said and meant in the primary discourse. According to Hyland, metadiscourse is the cover term for the self-reflective expressions used to negotiate interactional meanings in a text, assisting the writer (or speaker) to express a viewpoint and engage with readers as members of a particular community. It is used to describe the author (speaker) how to organize their own ideas and how to contact with reader (hearer).

A number of metadiscourse taxonomies on metadiscourse resources have been developed. Among them, Hyland [4] adopts a functional approach to distinguish two categories of metadiscourse, namely interactional and interactive resources. Interactive resources are features which are used to organize prepositional information in ways that a projected target audience is likely to find coherent and convincing, whereas Interactional resources are features involving readers and open opportunities for them to contribute to the discourse by alerting them to the author's perspective towards both propositional information and readers themselves. The classification is shown as follows.

TABLE I Classification of Metadiscourse

\begin{tabular}{|l|l|l|l|}
\hline \multicolumn{1}{|c|}{ Category } & \multicolumn{1}{|c|}{ Subcategory } & \multicolumn{1}{c|}{ Function } & \multicolumn{1}{c|}{ Examples } \\
\hline \multirow{5}{*}{ Interactive Resource } & Transitions & Express relations between main clauses & In addition; but; thus; and \\
\cline { 2 - 4 } & Frame Markers & Refer to discourse acts, sequences or stages & Finally; my purpose \\
\cline { 2 - 5 } & Endophoric Markers & Refer to information in other parts of the text & See fig; in section 2; noted above \\
\cline { 2 - 5 } & Evidential & Refer to information from other texts & According to X; Z states \\
\cline { 2 - 5 } & Code Glosses & Elaborate propositional meanings & Namely; in other words \\
\hline \multirow{5}{*}{ Interactional Resource } & Hedges & Withhold commitment and open dialogue & Possible; might; perhaps \\
\cline { 2 - 5 } & Boosters & Express writer's certainty or close dialogue & In fact; definitely; It is clearly that \\
\cline { 2 - 5 } & Attitude Markers & Express writer's attitude to propositions & Surprisingly; I agree \\
\cline { 2 - 5 } & Self-mention & Explicit reference to author(s) & I; me; mine; we; ours \\
\cline { 2 - 5 } & Engagement Markers & Explicitly build relationship with reader & You may see that; consider \\
\hline
\end{tabular}

\footnotetext{
* This work is supported by Major Research Program of Xiangsihu College of Guangxi University for Nationalities \#2011KY208
} 


\section{Independent College Students' Writing Competence}

There have been certain discussions on college English writing in past decades, whereas most of them focus on students from key universities and colleges. Little Emphasis has been placed on students from independent colleges. Compared with those from key universities and colleges, independent college students are accepted to college with lower entrance examination scores, most of whom are less capable in English, especially in English writing. According to results of CET4, their writing competence is below average with an average score between 5 and 7 , while the full mark for the writing section is 15 .

To better study their writing problems, 60 compositions, with the same title from CET4, are selected from students of Xiangsihu College of GuangXi University for Nationalities. All the compositions are completed within 30 minutes with about 120 words. They are analyzed from metadiscourse perspective within Hyland's framework. Main problems are summed up as follows.

\section{A. Inadequacy of Interactive Resources}

Interactive resources are used to organize information in a coherent and convincing way. One of the most common problems in Independent College students' compositions is the inadequacy of such devices. For example:

The problem of population aging will bring some problems. For example, it will give more pressure on young people. And it may prevent the economy progressing. Population aging calls for better medical service and it may cause some unknown problems.

In this paragraph, the writer is representing problems that caused by population aging, but no transitions are found between the third and the fourth sentence, thus failing to achieve coherence.

\section{B. Inadequacy of Interactional Resources}

Interactional resources enable writers to make their views explicit and to involve readers by allowing them to respond to the unfolding text. Hedges are the most frequently used device of this kind and they are adopted to reduce affirmation of argument. However, they are often neglected in students' composition. For example:

Aging of population mentioned above will bound to generate severe consequence if we keep turning a blind eye and deaf ear to it. On the one hand it will aggravate society's burden; on the other hand, it will bring about some unknown problems.

In this example, the writer is expressing his concerns about population aging, but without hedges it sounds somewhat affirmative.

Another kind of interactional resources is attitude markers, such as agree and prefer. They indicate the writer's affective attitudes to propositions, which can express surprise, agreement, pleasure, importance and so on. Students are required to express opinions towards the discussing topic in CET 4 composition, but sometimes their views are not clearly represented due to lack of attitude markers. For example:
Population aging can increase the burden on society. The measure to tackle it is to have more children. The government should encourage the family which has fewer children or no child.

It is obvious that the writer is trying to emphasize viewpoints, but failing to achieve this goal without proper attitude markers.

\section{Application of Metadiscourse to English Writing}

From the above examples, it can be seen that inadequacy of metadiscourse may result in students' low grades in CET4 compositions. Therefore, it is practical to apply metadiscourse into teaching English writing in order to enhancing independent college students' writing competence.

Since there is no English writing classes for non-English majors, teachers could focus students' attention on metadiscourse in textbook in College English classes. How metadiscourse is used to achieve coherence and represent views in paragraphs could be studied, so students would comprehend the important role of metadiscourse in text organization. For some frequently used metadiscourse devices, teacher could give students detailed explanations with examples.

However, in order to avoid students' misuse of metadiscourse devices, it is essential for the teachers to design different kinds of exercises for the students so that they can get to know which devices they tend to use inappropriately.

Besides, it is better to show students some learning materials concerning metadiscourse which are written by the native speakers so that they can learn the way native speakers using metadiscourse. Teachers can also play the recordings on metadiscourse resources which are spoken by the native speakers. Thus, the students can acquire how the native speakers use metadiscourse resources and use them appropriately.

\section{Conclusion}

Metadiscourse is related to successful oral and written communication. The study shows that students' compositions are lack of metadiscourses devices, which to some extents leads to their failure in English writing. Taking this situation into account, metadiscourse should be taught systematically in English classes and students need to learn to use such resources correctly.

\section{Acknowledgment}

This paper is supported by Major research Program of Xiangsihu College of Guangxi University for Nationalities (2011KY208)

\section{References}

[1] Z. Harris, "The transformational model of language structure," Anthropological Linguistics, vol. 1, no. 1, pp. 27-29, 1959.

[2] V. Kopple and J. William, "Some exploratory discourse on metadiscourse," College Composition and Communication, vol. 36, no. 1, pp. 82-93, 1985. 
[3] A. Crismore, R. Markkanen and M. S. Steffensen, "Metadiscourse in persuasive writing: a study of text written by American and Finnish university students," Written Communication, vol. 10, no. 1, pp. 39-71, 1993.
[4] K. Hyland, Metadiscourse: Exploring Interaction in Writing, London: Continuum, 2005. 